\title{
'Like Father, Like Son'? The Woman as a Bargaining Object in Gen 20:1-18 and Gen 26:1-11
}

\author{
GESILA UZUKWU (NASARAWA STATE UNIVERSITY, NigERIA)
}

\begin{abstract}
Abraham and Isaac separately 'used' their wives to stay alive. Viewed, on one hand, as a pragmatic approach to life, the choice made by father and son demonstrates a moral failure that caused them to 'sacrifice' their wives, turning them to objects that could be exchanged. Hence, the end of preserving their lives justifies the means (lying and cooperation in formal evil of adultery). On the other hand, the story of Isaac, following in the footsteps of his father, offers us a reflection on how certain human actions, while useful and valid at a given point in time, cannot be judged morally good/bad or worthy of emulation without reference to the intention and historical situation of the primary agent. In Gen 20:1-18 and 26:1-11, the five protagonists (Abraham, Sarah, Isaac, Rebecca and Abimelech) confront us with the perennial issues of patriarchy, the agency and compliance of women in reinforcing patriarchal patterns of politics and de-humanisation, the resilience and resistance of women in the face of the many forms of objectification and commodification as well as the error of repeating the mistakes of the fathers. Using a biblical social ethical approach, this article examines (a) how patriarchalism could and have fostered the objectification and commodification of women; (b) what themes from father and son communicate to the modern reader about the interplay of cause and effect in fostering a culture of gender violence and instrumentalisation of women, as well as (c) how the female protagonists' response to the situation of exploitation (especially sexual exploitation) and objectification could inspire modern women to break boundaries that negate female flourishing.
\end{abstract}

KEYWORDS: Abraham, Sarah, Isaac, Rebecca, Abimelech, sisterwife stories, objectification of women, patriarchy

\section{A INTRODUCTION}

The treatment of the women mentioned in the sister-wife stories of Gen 12:1020, 20:1-18, 26:1-12 and the ethical implications are the focus of this study. Scholarship on Gen 12:10-20, 20:1-18, 26:1-12 has involved the reconstruction

* Submitted: 01/01/2021; peer-reviewed: 28/04/2021; accepted: 08/05/2021. Gesila Uzukwu, "'Like Father, Like Son'? The Woman as a Bargaining Object in Gen 20:118 and Gen 26:1-11," Old Testament Essays 34 no. 1 (2021): 89 - 113. DOI: https://doi.org/10.17159/2312-3621/2021/v34n1a7. 
of the tradition, source or the redactional process behind the triplet or doublet as it is presented. Only recently has there been a renewed interest in the ethical, theological, social and political ideologies in the text as areas that can help clarify the meaning of the text for present readers. Despite the effort, more and more attention is still given to texts from the point of view of the Abrahamic tradition and how the sister-wife stories fall into the grand narrative of God's covenant with Abraham.

Genesis 12:10-20, 20:1-18 and 26:1-12 narrate stories of Abraham and Isaac (12:10-20 and 20:1-18 is about Abram and 26:1-12 is about Isaac), who in their bid to deal with threats of famine passed their wives in exchange for safety and wealth. In two, out of the three versions of the story, Abraham and Isaac make same or similar claims about their wives, as other features in the narrative, such as repetition of event, character and setting, continue to question the relationship between all three narratives. The idea that we have a doublet or triplet account of the same/similar event may be because of a literary process, as Documentary Hypothesis struggles to determine the tradition and redaction behind the narratives.

However, our interest in these literary narratives is to see what moral lessons can be made of case stories that involve father and son's unethical actions towards their wives. As with every ancient story, especially biblical narratives, one important task of exegetes is to reread stories to be able to provide moral, theological and social lessons for present day readers. If the stories of Abraham and Isaac can be imagined as actual narratives, we see before us narratives that can relate to our stories; of sons following the footsteps of the fathers, of the problem of deception, of husbands objectifying their women, of patriarchalism (in this context of male control and fear), of female subordination, of women's struggle with feminine beauty, self-sacrifice, women's sexuality as well as the social-ethical implications thereof. On a positive note, it will also highlight how women have always come to the rescue in situations, including the situations of resistance and resilience in the face of oppression. These are stories that we can see ourselves in, as they become exemplars of our everyday life.

For a closer analysis of the actions of Abraham and Isaac in relation to Abimelech, our synoptic comparison of the sister-wife stories focuses only on Gen 20:1-18 and 26:1-12, since the surrounding context, location, characters in the narrative and subject matter share the same or a similar message. Using a biblical-ethical approach, this study evaluates the ethical behaviour of the characters in the text, especially Abraham, Isaac, Abimelech and the courtiers of Abimelech and how they can be linked up with the wider ethical issues of our time such as utilitarian ethics, conspiracy of silence, deception, patriarchal patterns of politics, power and control as well as the power of women in solving problems. In addition, the study examines the characters of Sarah and Rebekah, 
Uzukwu, "Woman as a Bargaining Object," OTE 34/1 (2021): 89-113 91

how their different negotiations with their husbands offer fresh perspectives on the role of women in tackling structures and the ideologies of patriarchy.

\section{B SISTER-WIFE STORIES IN GEN 12:10-20; 20:1-18 AND 26:1-12: A CONTINUOUS NARRATIVE}

The book of Genesis has three passages dealing with the Patriarchs of Israel passing their wives as their sisters before foreign kings namely Gen12:10-20; 20:1-18 and 26:1-12. In response to fear for their lives, safety and wealth, Abraham and Isaac said that their wives (Sarah in the case of Abraham and Rebekah in the case of Isaac) were their sisters. Efforts to understand the message of the passage has ranged from discerning the source of the narrative, the tradition behind the narrative and the theme of the narrative.

Working with the hypothesis that the narratives are related thematically and structurally, one of the assumptions is that out of Gen 12:10-20;20:1-18 and 26:1-12 is one original narrative, while the others are redactions of the first. In the words of Robert Culley, the sister-wife tales are versions of a single story that had existed in an oral form. ${ }^{1}$ John Van Seters with Claus Westermann and few others argue that Gen 12:10-20 is the earliest of the three, while the other two are dependent on it. ${ }^{2}$ Martin Noth ${ }^{3}$ and E. A. Speiser, on the other hand, suggest that Gen 26:1-12 (that is, the Isaac version) is the original, while the others are redactions on the account of variant traditions.

Drawing from the gamut of discussions on the Elohist and Yahwist as two major sources behind the Pentateuch, the other debate is that one of the Abraham narratives belongs to the Elohist (E) while the Isaac story is attributed to the Yahwist (J). ${ }^{4}$ This, in turn, means that the two narratives under study belong to two different traditions, that is, Gen 20:1-18 belongs to the Elohist while Gen 26:1-12 belongs to the Yahwist.

Besides the debate on the source(s) or traditions behind Gen 12:10-20; 20:1-18 and 26:1-12, there is the scholarly attempt to determine the shared/single meaning of the stories. Following the hypothetical documentary argument, one

1 Robert C. Culey, Studies in the Structure of Hebrew Narrative (Philadelphia: Fortress, 1976), 39.

2 John Van Seters, Abraham in History and Tradition (New Haven: Yale University Press, 1975), 167-248; Claus Westermann, Genesis 12-36: A Commentary (Minneapolis: Augsburg Press, 1985), 346-347.

3 Martin Noth, A History of Pentateuchal Traditions (Englewood Cliffs: PrenticeHall, 1972), 102-109.

4 Noth, A History of Pentateuchal Traditions, 22; Ernest A. Speiser, Genesis (Garden City: Doubleday, 1964), 150-152; Bruce Vawter, On Genesis: A New Reading (Garden City: Doubleday, 1977), 244 and 251; Claus Westermann, Genesis 12-36: A Commentary (Minneapolis: Augsburg Press, 1985), 346-347. 
of the suggestions is that the repeated narratives serve to emphasise the ethical monotheism and the religious values of Israel. According to C. A. Keller and David L. Petersen, all three narratives are independent constructs built around unique motifs that are not common in all three versions. Although the stories share the motif of the patriarch who lies about his wife to save himself, there are non-shared motifs from realms of universal, historical, religious-cultic, juridical, and humorous experience that are combined in distinctive ways in each of the specimens. It is in the context of the non-shared motifs that Gen 12 points to the contrast between Abraham's plan and Yahweh's plan; that Gen 20 embodies two central themes - a dialectic of sin, which emphasises that, although no one may be said to be solely guilty, it remains the case that Elohim has been affronted; and Gen 26 carries the theme of patriarchal success in a foreign context. ${ }^{5}$

Focusing on the serving function of the narratives, Susan Niditch is of the opinion that the stories in Gen 12:10-20;20:1-18 and 26:1-12 offer a picture of Israel's peculiar self-image as the underdog and trickster, who in the many afflictions that befell it was able to overcome. The repetition, she emphasises, depicts the many times the people of Israel faced hostile situations and they had to trick again to succeed. ${ }^{6}$ For Robert Alter, the wife-sister stories, like some other narratives, are not historical narratives. They are, he claims, exemplary narratives, "purposefully deployed literary conventions" with fixed motifs concerning the lives of the hero(s) of the narrative. ${ }^{7}$ Serge Frolov explains that the three sister-wife stories are literary examples of "self-returning magic object" whereby Abraham and Isaac manage to access some of the divine favour repeatedly promised them on a grand scale (Gen 12:2-3, 7; 15:1-21; 17:1-8, 1521; 18:17-19; 22:16-18), using Sarah and Rebekah as "self-returning magic" entities. $^{8}$

Given that scholarly assumptions about the connection between the three sister-wife narratives in Genesis have not entirely solved the problem of the relationship between Gen 12:10-20; 20:1-18 and 26:1-12, our examination of Gen 20:1-18 and 26:1-12 can further help invite reflections on the relationship

5 David L. Petersen, "A Thrice-told Tale: Genre, Theme, and Motif" Biblical Research 18 (1973): 30-43; A. Keller, "Die Gefaihrdung der Ahnfrau': Ein Beitrag zur gattungs- und motiv- geschichtlichen Erforschung alttestamentlicher Erzahlungenr," ZAW 66 (1954): 185, 186, 189-190.

6 Susan Niditch, Underdogs and Tricksters: A Prelude to Biblical Folklore (San Francisco: Harper \& Row, 1987), xv-xvi.

7 Robert Alter, The Art of Biblical Narrative (New York: Basic Books, 1981), 4950.

8 Serge Frolov, "Sarah, Rebekah, and the Unchangeable Ruble: Unrecognized Folkloric Background of the "Wife-Sister" Stories in Genesis," Biblische Notizen 150 (2011): 3-8, 5. See also Stith Thompson, Motif-Index of Folk-Literature, II (Centraltrykkeriet: Copenhagen, 1956), 280. 
Uzukwu, "Woman as a Bargaining Object," OTE 34/1 (2021): 89-113 93

between the stories of Abraham and Isaac especially in connectioned with Abimelech. Our discussion begins with the assumption that all three narratives could be read as distinct literary units, though having a close connection with their sister narratives.

The first chain of connection is in the import of the geographical locations of the narratives. Genesis 12:10-20 ended with Pharaoh sending Abraham out of Egypt when he discovered that Abraham had lied to him (12:17-20). In Gen 20:118 , another reference was made about Abraham lying concerning his relational status with Sarah, but this time, we were not told of the reason for their sojourn South (Negev). We know that in the course of their sojourn, they were at Gerar at the time. In Gerar, as in Egypt, Abraham met the same danger to his life and passed Sarah on as his sister. George W. Coats noted a similar point when he argues that the locale for Gen 20:1-18 was contained already in the previous Abraham sister-wife narrative. ${ }^{9} \mathrm{He}$ adds that Gen 12:9's reference to Abraham's itinerary towards the Negev, the wordplay in the verb sojourned (wayyaggarr) and the place name Gerar (bigrār) connects Gen 12:10-20 with 20:1-18. We find also in Gen 20:1 the statement "and he journey from there" (wayyissa ' mišš $\bar{a} m$ ) as a possible reference to the rhetorical, geographical and narrative movement of the sister wife stories that began in 12:10-20. Besides that the occasion of deceit is coming up a second time in Gen 20:1-18, the, where Abraham statement to Sarah in 20:13 that "at every place to which we may come, say of me, He is my brother" allows us to see the movement from Egypt to Gerar as a continuation of event. This movement of Abraham culminated in the presence of Isaac in Gerar.

At the beginning of the narrative of Isaac in Gerar (Gen 26:1-12), we read that Isaac had left for Egypt because there was a famine in the land. Along the way, the Lord appeared to him and warned him not to go down to Egypt but to settle in Gerar (26:2-3a). Without being informed by God, Isaac could have been aware of the encounter between his father and Pharaoh and would have avoided going down to Egypt. One could claim that he also probably was unaware of the encounter because the Pharaoh in the narrative of Isaac might not have been the same king who dealt with Abraham several years earlier. In any case, the message of the Lord cleared Isaac of getting into the same moral problem and its consequences, as the father with Pharaoh. Nevertheless, Isaac was caught in the same recurrent motive of deceit as his father.

As in the case of Abraham in Gerar, Isaac also went down to Gerar to reside as an alien (20:1 and 26:3). While in Gerar, Abraham and Isaac said of their wives, "she is my sister." Through divine intervention in the case of Abraham/Abimelech and Abimelech watching through the window in the case of Isaac/Abimelech, the truth of the status of the wives was discovered (20:3-7

9 George W. Coats, Genesis, with an Introduction to Narrative Literature (Grand Rapids: Eerdmans, 1983), 149. 
and 26:8). In both narratives, we learn that any attempt on the part of the king or his subjects to take the wives of the patriarchs would have resulted in the death of the patriarch $(20: 3,7$ and 26:11).

The other aspect of the stories is the responses of the women, whether as reported speeches, recorded actions or silence. In reading the stories of Sarah and Rebekah, we see how the women's silence, consent, matriarchal lies, actions and reactions offer insight into deeper understanding on the position of women in patriarchal narratives and their impact. First, of note is that the different narratives project different reactions from the women in the three sister-wife stories. Previous scholarship has interpreted all three narratives as a demonstration of patriarchal consciousness and ideology that silences or ignores women or denies women a voice in stories in which they starred. Thus, Sarah and Rebekah were denied a narrative voice, rendering it impossible to know what their reaction would have been. They were either rendered powerless to express their rejection of the wrong move made by their husbands to determine their sexual status and control over how their sexuality is perceived ${ }^{10}$ or else they were forced to accept the situation for, according to Niditch, Sarah was a tacit accomplice. ${ }^{11}$ Cheryl Exum argues to the contrary that, in the sister-wife stories, both Sarah and Rebekah are silenced because the story is not about them. The women, she claims, were only objects in a story about male fears and desires. ${ }^{12}$

Given the overwhelming patriarchal nature of Israelite literature, it also follows that the sister-wife narratives are glaring examples of stories of the troubling silence of women in Israelite narratives. Presuming what could be the Jewish custom at the time, one can argue that the silence of the women, especially of Sarah was not out of place since the role of women in the biblical text was very much repressed. As such, neither Sarah nor Rebekah would have engaged in any discussion with their host. However, this is not entirely so especially with Rebekah and even Sarah. Sarah and Rebekah were not completely passive. In fact, there is a certain line of development or narrative progression from the silence of Sarah, her reported speech which gives a clue to what went on in Sarah's mind and the consequences of her action, to Rebekah's recounted action that can be analysed as a form of resistance to the sexual oppression of women.

The three sister-wife narratives are not duplications of one narrative. The characters of Sarah and Rebekah are not just repetitions of the silence of the

10 Sharon Jeansonne Pace, The Women of Genesis: From Sarah to Potiphar's Wife (Minneapolis: Fortress Press, 1990), 17.

11 Niditch, Underdogs and Tricksters, 59. See also Hugh C. White, Narration and Discourse in the Book of Genesis (Cambridge: Cambridge University Press, 1991), 185.

12 Cheryl J. Exum, Fragmented Women Feminist (Sub)versions of Biblical Narratives (JSOT Press: Sheffield, 1993), 165-166. 
Uzukwu, "Woman as a Bargaining Object," OTE 34/1 (2021): 89-113 95

matriarchs. In the first and second narratives, Sarah was silent - but it was a complicit silence that highlights how women could be accomplice and participants with men in the confrontation of social realities that attempt to destroy the essence of human life and living (cf. Gen 20:5). In the second narrative, Sarah agreed with Abraham on what to say, despite the distress that came upon her as a result of their encounter in Egypt. Faced with the reality of their present situation, that is, famine, Sarah probably gave her consent not just to please Abraham but also to collaborate with her husband in dealing with the present social economic crises, though without evaluating the ethical implications, which would go far beyond her intentions. According to Esther Fuchs, it is one of the patriarchal ideologies of Old Testament narratives to portray the role of women as that of giving support to patriarchal arrangement. ${ }^{13}$

The third narrative takes a different turn, as Abimelech witnessed an unmediated revelation of the relational status between Isaac and Rebekah, seeing the couple fondling themselves in the open. In the third narrative, Rebekah was seen playing with Isaac in the open (wayyar, wahinnêh yișhāq mașahêeq 'êt ribquāh 'ištoww, Gen 26:8). The verb used here, sahaq, could mean 'to laugh,' 'make jest' or 'have fun. ${ }^{14}$ According to Mary Phil Korsak, the piel form of the verb, as also used in Gen 26:8 suggests intensive or repetitive laughter which comes with sexual fun. ${ }^{15}$ In the case of Rebekah and Isaac, Abimelech saw Isaac engaging in publicly displayed affection (metsaheq) with his wife Rebekah.

Sexual relationship is an act that should be or is given maximum privacy, usually restricted within the confines of the home. By displaying their affection in the open space, Isaac and Rebekah, were sending a non-verbal message of resistance against and rejection of the possibility of taking Rebekah into another man's harem. While the behaviour may have alerted Abimelech of the true nature of the relationship between Isaac and Abimelech, the use of a public space to display their affection, especially deliberate sexual affection, was already a mockery/laughter against Abimelech who had bridged the boundaries of other people's privacy. Although Rebekah might have been silent, her actions left Abimelech thinking, coming back to his senses, taking actions, and most

13 Esther Fuchs, Sexual Politics in the Biblical Narrative Reading the Hebrew Bible as a Woman (Sheffield: Sheffield Academic Press, 2003), 32.

${ }^{14}$ William L. Holladay, A Concise Hebrew and Aramaic Lexicon of the Old Testament: Based upon the Lexical Work of Ludwig Koehler and Walter Baumgartner, A Concise Hebrew and Aramaic Lexicon of the Old Testament (Grand Rapids: Wm. B. Eerdmans, 1971), 305.

15 Mary Phil Korsak, "God's Laughter," in Building Bridges in a Multifaceted Europe: Religious Origins, Traditions, Contexts and Identities (ed. Sabine Bieberstein, Kornélia Buday and Ursula Rapp; Leuven: Peteers, 2006), 171. 
importantly, avoiding coveting another man's wife. What then can we say about the action of Rebekah in the context of the sister-wife stories?

\section{BARGAINING MOTIF IN GENESIS AND ITS IMPLICATION FOR THE SISTER-WIFE STORIES}

Bargaining motif is one of the recurring patterns used in Old Testament narratives to underscore how power relationships can induce certain social practices, which contribute to one of the stereotype representations we have of the patriarchs. Bargaining motifs, or rather, negotiation narratives are very much present in Old Testament narratives. A study of Genesis reveals at least 23 narratives that contain bargaining motifs (Gen 12:10-20; 13:8-12; 16:1-6; 19:3038 ; 20:1-18; 21:22-34; 24:1-10; 25:29-34; 26:1-11, 26-33; 27:1-46; 29:15-30; $37: 12-36 ; \quad 30: 1-9 ; 38: 6-11, \quad 12-26 ; \quad 42: 18-43: 16$; and 44). With such overwhelming presence of bargaining narratives in Genesis, one wonders what the general purpose of such narratives in the stories of the patriarchs could be, and more so, of the sister-wife narratives.

Our study begins with one of the scholarly observations that bargaining narratives can be presented and studied as instances of trickery or deception narrative in Genesis. ${ }^{16}$ Under the assumption that the passages listed above present variety of ways which different characters used various deceptive, dishonest or even violent means to meet a need, scholarly debate has become an argument over whether or not the ancestors of Israel could be excused of wrongdoing. On one hand, traditional exegetes (Jewish and Christian) have tried to exonerate the matriarchs and patriarchs of Israel of moral culpability, since their acts of deception were counter reaction to persecution, coercion or even compulsion. ${ }^{17}$ Others, like Ernest A. Speiser and Samuel Greengus, argue that deception in Genesis was borne out of the culture of the time, especially the incidents in wife-sister narratives and Jacob's obtaining Isaac's blessing as part of the Hurrian legal practices. ${ }^{18}$ Modern scholarship, on the other hand, read some of the texts in the light of how God's promise came to fulfilment. For instance, D. J. A. Clines suggests that Gen 12-50 revolves around the concern for posterity, stating that, "In our view the Abraham cycle is dominated by this theme and more precisely with the question, who will be Abraham's heir?"19

16 See Niditch, Underdogs and Tricksters.

17 Robert B. Robinson, "Wife and Sister through the Ages: Textual Determinacy and the History of Interpretation," Semeia 62 (1993): 103-104; Philo, Volume VI: On Abraham. On Joseph. Moses I and II (Cambridge: Harvard University Press, 1950), 53. 18 Ernest A. Speiser, "The Wife-Sister Motif in the Patriarchal Narratives," Biblical and Other Studies I (ed. A. Altmann; Waltham: Brandeis University Press, 1963), 1528; Samuel Greengus, "Sisterhood Adoption at Nuzi and the 'Wife-Sister' in Genesis," HUCA 46 (1975): 5-31.

19 D. J. A. Clines, The Theme of the Pentateuch (Sheffield: JSOT Press, 1978), 45. 
Uzukwu, "Woman as a Bargaining Object," OTE 34/1 (2021): 89-113 97

While previous discussions have helped to open interesting dimensions about the use of deception motif in Genesis, a further interest in the narratives establishes the distinctive features, settings, rationale and implications of deception in narratives involving women, asking questions about the effect of deception on women who are made objects of bargain in Genesis. Most of the Genesis narratives mentioned at the beginning of this section are all situated within the context of negotiation dialogues. Negotiations range from dialogue over land (13:8-12), child (16:1-6; 19:30-38; 38:6-11; 12-26; 30:1-9), wife (24:1$10 ; 29: 15-30)$ property/wealth (Gen 12:10-20; 20:1-18; 26:1-11), freedom (42:18-43:16, and 44), peace treaty $(21: 22-34 ; 26: 26-33)$, supreme authority and privileges (37:12-36) and other contents of the law such as birth right (25:29-34; 27:1-46). In negotiations, there are the bargaining partners, the object of bargain, the key purpose of the bargain and the resolution.

While there are many reasons characters enter into dialogue of negotiation, of interest to us are the questions around the use of women as bargaining objects when compared with other objects of exchange. A casual reading of the passages mentioned above observes Gen 12:10-20; 16:1-6; 20:118; 26:1-11 and 30:1-9 as passages that position women at the centre of patriarchal bargain. ${ }^{20}$ On the possible link between the narratives is the expression "Hinai-na" (Behold, I pray thee), which is used as a particular form of supplication found in all the narratives (cf. Gen 12:11; 16:6; 20:15, 16;26:9; 30:3). Statements with "Hinai-na" are usually appeal statements. They take the form of negotiations, but negotiations with a suppliant who appeals to a defendant for help. No matter what the appeal is, grounds for appeal are usually that of precarious situations. They are situations where defendants are left with little or no option. It also highlights the possible peril that may be encountered if the bargain should take place.

In the case of the stories of Abraham and Sarah, and of Rachel and Jacob, the mothers made requests to their husbands and there is evidence that the patriarchs immediately accepted the supplications of their wives to use their slaves to give them children, regardless of whether the slave girl wanted the bargain or not. ${ }^{21}$. Of course, the situation of Hagar and Bilhah expresses one of the traditions concerning the use of slaves in ancient Jewish and Greek society, namely that masters had sexual rights over their slaves. According to Catherine Hezser "slaves were sexually exploited in both Jewish and Graeco-Roman

20 The word 'patriarchal bargain' was first coined by Deniz Kandiyoti in her 1988 article, "Bargaining with Patriarchy," Gender and Society 2 (1988): 274-290, 275, as she attempts to understudy how women respond to concrete constraints of different types of patriarchal systems by accepting gender rules that are unfavourable to them in order to survive.

21 Cf. Gen 16:2, "And Abram hearkened to the voice of Sara," and 30:4, "And Rachel gave him Bilhah her maid, for a wife to him"; and "Jacob went in to her." 
society. The phenomenon that masters would sleep with and produce children with their slaves is taken for granted by both Jewish and Roman writers." 22 Female slaves had no bargaining power.

In the other two instances where the matriarchs were used as objects for bargain, they were part of the bargaining party as well as the objects used for the bargain. In the account of Gen 20:1-18, the text admits that Sarah had also lied about the relationship with Abraham, making her an accomplice in a bid that will also endanger her life ("Did not he himself say to me, 'She is my sister'? And she herself said to me, 'He is my brother, 20:5). Rebekah on the other hand, probably also gave her consent, although the setting of the narrative did not indicate when such a dialogue took place. We shall come back to this in our discussion of the "laughing motif."

Questions about the status of women in Judaism have been discussed over time, producing enormous literature on the different controversies over the place, status and role of women in Judaism. The scholarly assumptions that the status of women in the early formative years of Judaism has important consequences for the interpretive and experiential paradigms of women today have remained an old long debate with no clear signs of abating. One of the arguments, which forms an important link to our contribution, is the aspect that women, alongside children and slaves, were regarded as properties of the ba'al (Exod 21:28, meaning, owner and lord of the family, who could be either the husband or father). Old Testament texts such as Exod 20:17and Deut 21:14 ${ }^{23}$ give us one of the first-hand clues about the status of women, especially in the socio-political and economic life of the Jews.

More than the above mentioned, one of the evocative issues in the story of the patriarchs is that the matriarchs were used for sexual bargain. Isaac sought the beauty of Rebekah as a resource in exchange for his life and Abraham did the same (cf. Gen 12:14). Why should beauty be used as a ploy to obtain riches? Female beauty is objectified as a commodity that can be used in exchange for power (economic and political), wealth, fame and even pleasure. In objectifying the matriarchs, Abraham and Isaac made them vulnerable to use by others. Although the matriarchs escaped being sexually used by their host, we know that

22 Catherine Hezser, Jewish Slavery in Antiquity (New York: Oxford University Press, 2005), 386.

23 "You shall not covet your neighbor's wife; you shall not covet your neighbor's house or his field or his male slave or his female slave or his ox or his draft animal or any animal of his or whatever belongs to your neighbour" (see also Deut 5:21) and Deut 21:14: "And it shall be, if you do not want her, you shall send her away free, and by a sale she shall not be sold for money. You shall not break faith with her, since you have humbled her." 
such avoidance was possible only through God's intervention (especially in the case of Sarah).

In the negotiation which took place between Abraham and Sarah and between Isaac and Rebekah (Gen 20:1-18 and 26:1-11), it has been recognised traditionally that these passages are part of the deception narratives of Genesis. This is true especially when the passages are viewed from the point of Abraham and Isaac's response to the Gerarites in 20:2:

"And Abraam said of his wife Sarra, "She is my sister," for he was afraid to say, "She is my wife," lest perhaps the men of the city kill him on her account." In 26:7, "Then the men of the place asked about his wife Rebekka, and he said, "She is my sister," for he was afraid to say, "She is my wife," lest perhaps the men of the place kill him for the sake of Rebekah, because she was attractive in appearance." However, the aspect of the negotiation between Abraham and the Gerarites and between Isaac and the Gerarites is much more important because it accentuates the conflict and tension in each of the narratives especially the political, economic, psychological, moral and social impact of using women as bargaining objects.

As the story continues, we see that Abraham and Isaac were shamed for their treacherous acts. Abimelech rebuked both Abraham and Isaac for their dishonesty (20:9 and 26:10). The expression meh 'ásit ța lānu ("what have you done to us") used in 20:9 and mah-zo't 'ásît ("what have you done") used in 26:10, are statements that accuses a character of wrongdoing, a wrongdoing that deserves punishment, and most importantly, a wrongdoing that hurts. We find the expression, mah-zo't 'ásitt, also in Gen 4:10, Gen 3:13 and Gen 29:25 and each time it is used, one notes that the question mah-zo' 'ásít is a confrontation that usually follows a premeditated evil act that is discovered. ${ }^{24}$

In responding to the question, mah-zo't 'ásît, Abraham and Isaac gave different reasons for the lie. In contrast to Gen 20:11 where Abraham claimed that he lied because he thought that Gerar was a place devoid of God, Isaac claimed he lied because he was afraid of losing his life (26:7). According to Sarna, Abraham's defence invokes the state of a society where there is a weak legal structure, as such, there is extraordinarily little or no restraint on the extent one could go to commit evil. Abraham lied with the consciousness that the supreme power would place a restraint on the evil that could befall him because

24 When the thought of Cain's heart was evil, he plotted and killed his brother Abel. God confronted him with the question, mah-zo't 'ásít (Gen 4:10). Stuck with the dilemma of good and evil, Eve gave Adam the forbidden fruit and God confronted her with the question mah-zo't 'ásít (Gen 3:13). When Laban tricked Jacob into having marital relations with Leah in the place of Rachel, Jacob called Laban and asked mah$z o$ 't 'ásít (Gen 29:25). These are the very few references where the expression mah-zo't 'àśît is used in Genesis. 
of Sarah. ${ }^{25}$ Though there are seeming differences in the responses of Abraham and Isaac, a closer observation reveals that all responses are within the framework of their religious experience of God, an experience that informed and shaped their life, practice, tradition and moral discernment.

Abraham, Isaac, Abimelech and the people of Gerar are all guilty of moral failure and lack of trust in God (for Abraham and Isaac). Abraham's and Isaac's faith in God could not overcome their life issues of fear, anxiety, desire and death. Abraham and Isaac may have pointed Abimelech to the absence of God in the land and its moral consequences. However, they were also a guilty party and that was the way Abimelech saw them. In the search for greener pastures, they found themselves at the crossroads of two evils and their choices left other characters in possible tragedy. Although one may argue that both Abraham and Isaac were incapacitated, they are responsible for the consequences of their lies. Abraham and Isaac may have accused the Gerarites of lack of fear of God and moral failure; but their denial of their wives also exemplifies moral and spiritual failure.

\section{ABIMELECH AND PAHARAOH: A STEROTYPICAL REPRESENTATION OF MEN AND SEXUAL FANTASIES AND ITS IMPLICATIONS}

In his article, "Looking through the Window: A Gendered Motif," Aaron Demsky argues that Abimelech looking out through the window was providential because it gave him a full picture of the reality, an insight that helped him avoid taking Rebekah as his wife. ${ }^{26}$ According to Don Seeman, Abimelech was able to discover the truth because the presence of Rebekah in Gerar (in a foreign land) posed danger to kingship ties or patrilineal union with inappropriate women. Thus, looking through the window helped to focalise the danger and moved Abimelech to actions that will extricate him and his household from a potentially devastating situation. ${ }^{27}$ Of note is that, in Seeman's analysis, Abimelech's gaze (as well as other male gaze in the Hebrew Bible) through the window is not just to be understood literally but as a cultural poetic device whereby the use of "significant spaces" signals narrative preoccupation with social boundaries, hierarchies, and oppositions. ${ }^{28}$

25 Sarna, Nahum, Genesis: The Traditional Hebrew Text with the JPS Translation (The JPS Torah Commentary. Philadelphia, PA: The Jewish Publication Society, 1989), 141.

26 Aaron Demsky, "Looking through the Window: A Gendered Motif," n.p Cited 2 February 2020. Online: https://www.thetorah.com/article/looking-through-thewindow-a-gendered-motif.

27 Don Seeman, "The Watcher at the Window: Cultural Poetics of a Biblical Motif," Prooftexts 24 (2004): 6-7.

28 Seeman, "The Watcher at the Window," 2. 
Uzukwu, "Woman as a Bargaining Object," OTE 34/1 (2021): 89-113 101

It is true that the location of an event is particularly important to understand the deeper significance of certain narratives, whether in the secret or the open space, on the street or in the temple, in the vineyard or the garden. Each of these locations could be used symbolically to represent religious, social or political situations or contexts within the text. While we accept that Abimelech was able to discover the truth of the relationship between Isaac and Rebekah by peering or looking through a window, an ethicist can hardly avoid questioning the moral stance of Abimelech, especially of using the window as a means of getting at a truth.

The act of peeping or looking through a window is usually an advantaged position of one who wants to discover the truth or learn about events without being noticed. Often however, the evidence of one who got his or her information by looking through the window is unacceptable because it may not give a clear picture of the situation. The other reason is that the knowledge obtained by peering through the window was not obtained through freedom, especially freedom of conscience. As such, one questions the moral basis for Abimelech's action. Could it be that Abimelech wanted to confirm secretly his foreknowledge of the story of Abraham and Sarah? Could no one else have discovered the truth except Abimelech?

It is one of the assumptions of this article that there is a certain connection between the Abimelech that lived at the time of Abraham and the one that lived at the time of Isaac and Rebekah. If the Abimelech in both narratives is not the same king, then, the younger Abimelech probably heard of what happened between the older patriarch and the king of Gerar. The knowledge of the tricks of the patriarchs may have reinforced the need to discover the truth, giving way to the window scenario. The other observation to be highlighted is the voyeurism of Abimelech, which remains a symbol of men's fascination with beauty and sex. The window narrative might not have been the first time Abimelech tracked the movements of Isaac and Rebekah. It remains highly likely that Abimelech looked through the window more than once because of the low moral standard of the people, awareness of the tricks of the patriarchs from Canaan or his sexual perversion.

We are remarkably familiar with stories of beauty and lust in the Old Testament especially in terms of men's intense desire to possess it. Pharaoh could not resist the beauty of Sarah therefore he ordered that she be brought into his harem (Gen 12:17). David was so blinded by Bathsheba's beauty that he sent Uriah (the husband of Bathsheba) to his death (2 Sam 12:18). Tamar was raped by her half-brother Amnon because of her beauty (2 Sam 13:1-20). Holofernes was captivated by the beauty of Judith and he desired to seduce and sleep with her (Jdt 6:4-5). 
Abimelech is not different. He was captivated by Rebekah's beauty (cf. Gen 26:7, "For Rebekah was attractive in appearance, and has desired to possess her"). Thus, there was an intention, a moral motif that makes an action good or bad. With Abimelech, there was already an evil intention which came to fruition when the opportunity offered itself. Men can be obsessed with beauty. Their fascination is in the psyche. It is an urge that can be quenched only when the object of beauty is possessed and used. By looking through the window, Abimelech's gaze traversed household boundaries and privacy. He saw what should happen within private spaces of one's home - sharing in one of the most intimate expressions of marital relationships, and so on. The act of looking or peeping through the window highlights one of the moral contents of the narrative.

The story of Pharaoh, on the other hand, and of how the Egyptians took Sarah into Pharaoh's harem because of her beauty captures the stereotypical understanding of how female beauty shapes the understanding of our reality and the world. Pharaoh learnt about the beauty of Sarah through his servants. Although upon sighting Sarah Pharaoh could have asserted Sarah's beauty, the act of bringing Sarah's beauty to the knowledge of Pharaoh helps to underscore what could be called a "shared concept."

In her psychoanalytic-literary reading of the sister-wife tales, Exum argues that Gen 12; 20 and 26 encodes the unthinkable and unacknowledged sexual fantasies found among men. She goes further to argue that "because there is something fearful and attractive to the (male) narrator about the idea of the wife being taken by another man, a situation that invites the woman's seizure," the narrative is repeated three times. ${ }^{29}$ In the repetition of the narrative, the narrator has tried to work out his "intrapsychic conflict," that is, the 'working out' of his sexual neurosis. ${ }^{30}$ Exum highlights the "desire of the beautiful woman" as the tension of the narrative which expressed itself in the fear of the patriarchs losing their lives because of the male's desire to possess the women. ${ }^{31}$

The mention of the beauty of Sarah (12:14) and of Rebekah (26:7) in the sister-wife stories raises questions not only about the sexual fantasies or neurosis of men but also how such sexual fantasies can generate a culture that dehumanises, oppresses and victimises women. The shared concept of feminine beauty as something to behold and use has not always worked in the favour of women particularly in the sense of the emotional and physical suffering women undergo because of their beauty and nature. The nurturing of sexual fantasies is an attitude that fosters the violation of women's bodies especially when their bodies are used without their consent. In addition, when such fantasies have been

29 Exum, Fragmented Women, 154.

30 Ibid., 155.

31 Ibid., 157. 
Uzukwu, "Woman as a Bargaining Object," OTE 34/1 (2021): 89-113 103

processed into cultures (traditions and customs), it becomes a belief system that directly or indirectly determines how women's life should be ordered, limiting femininity to objects of pleasure and desire without consideration to the plight of women.

\section{E RESILIENCE OF SARAH AND ITS SOCIAL MORAL IMPLICATIONS}

To speak of the resistance of the women in the sister-wife stories is to take a closer look at the actions of Sarah and Rebekah. As already pointed out, Sarah was not silent. However, the question is, why would Sarah accept to enter the harem of another man? To begin with, Sarah is the heroine of the story in Gen 20:1-18, but a tragic heroine. Like few other women whose stories are recounted in the sacred Scripture, Sarah made the ultimate sacrifice for the sake of her husband. She endured the hurt/pain of entering another man's harem to save the life of her husband. Esther, for instance, was willing also to put her life at stake for her people. ${ }^{32}$ Ruth, Naomi's daughter in-Law, agreed to Naomi's plot to lie with Boaz in order to secure progeny after the death of Ruth's husband (Ruth $3: 1-5)$.

Faced with crises (the danger of losing one's life, of destroying a nation or procuring a progeny), these matriarchs of the Old Testament risked their lives to change the course of events. Their actions depict the valour of women, the feminine power (a combination of determination, commitment, justice, emotion and care), with which women can reverse or transform life threatening situations. An appropriation of Gen 20:1-18 helps to highlight some of the contemporary issues about women. It points out one of the ways women endure much pain to save or change situations. In some cases, women are sacrificial victims for societal peace, political tussles, economic transformation and social justice.

Sarah was truly resilient but her resilience came with a price. Her compliance has been misinterpreted. While she shared in the ambition and vision of her husband, her action in Gen 20:1-18 has been misinterpreted as enforcing patriarchal oppressive ideologies. Directly or indirectly, the compliance of Sarah has helped a certain reading of the matriarch's story to portray how women participate in promoting cultures and customs that debase womanhood and femininity. In the article, "Religion and Religiosity of Women in the Scripture and Africa: A Study of a Living Paradox," Gesila Uzukwu emphasised how

32 "Go, gather together all the Jews that are present in Shushan, and fast ye for me, and neither eat nor drink three days, night or day: I also and my maidens will fast likewise; and so will I go in unto the king, which is not according to the law: and if I perish, I perish" (Est 4:16 KJV). 
women participate with men in fostering and permeating patriarchal prejudices and experiences that are detrimental to the lives of women. ${ }^{33}$

Femininity is continuously objectified, either in the form of selfobjectification or patriarchal objectification of women. The issue of selfobjectification is also raised here because the exposition of the silence (or rather tacit agreement) of Sarah has been related to how women of our time submit to themselves to physical, psychological and emotional trauma in a bid to keep their marriage, friendship, family or work. The situation becomes even more abusive when a woman (or female adult) is requested to endorse or involve herself in any form of self-objectification based on a man's feelings and emotions such as lust, anger, disgust, fear, joy and pride. The high rate of sexual violence in our society, including human and sexual trafficking, rape (also rape incurred through forced marriages), domestic violence which includes sexual abuse, sexual harassment in the workplace and places of worship, are socially constructed evils that destroy the dignity and self-worth of women.

Example also could be cited of modern-day notions of feminism whereby women impose or take on themselves certain notions of sexuality and sex, sexual freedom, expressions of beauty and a sense of liberation that degrade women, but advance, legitimise and reinforce patriarchal stereotypes, attitudes, and ideologies about women and femininity. ${ }^{34}$ In the many ways, women make themselves object of male delight, thoughts, feelings and pleasure, they are both directly and indirectly affirming the patriarchal myth that women are the means to an end, beings possessing lesser moral status and mere instruments through which the sexual needs of men can be met. ${ }^{35}$

The observations above, however, cannot be the point of the narrative. A better appreciation of the silence of Sarah in Gen 12:11-20 and her reported statement in 20:5 lies in a clearer understanding of the use of and the power of silence in Old Testament narratives. According to Paolo Torresan, silence is used in Old Testament narratives not only to depict situations of grief or mourning or to deny a character a voice but also as a "lively force" that is effective enough to

33 Gesila Uzukwu, "Religion and Religiosity of Women in the Scripture and Africa: A Study of a Living Paradox," Abuja Journal of Philosophy and Theology 4 (2014): 37-55.

34 Christopher Bartak, Held down through Their Bodies: Sexual Objectification of Women and the Legitimization of Patriarchy (Ph.D. diss., University of Oklahoma, Graduate College, 2015), 6.

35 D.H. Gruenfeld, M.E. Inesi, J.C. Magee and A.D. Galinsky, "Power and the Objectification of Social Targets," Journal of Personality and Social Psychology 95 (2008): 111-112; Sandra Lee Bartky, Femininity and Domination: Studies in the Phenomenology of Oppression (New York: Routledge, 1990), 26. 
Uzukwu, "Woman as a Bargaining Object," OTE 34/1 (2021): 89-113 105

change the lines of narratives. ${ }^{36}$ Interestingly, the silence of female characters has been emphasised greatly as a way of underscoring patriarchy, male superiority and domination of power in Old Testament narratives. However, silence is not always a negative thing.

In the case of Sarah, her silence may have been interpreted as a form of acceptance of an oppressive situation but it is not a submissive silence that leads to despair. Her silence was an act that looked beyond the present situation to offer a better tomorrow. Secondly, it is an act that elevated family objectives over individual priorities and gains. Sarah knew that her role was to assist her husband, as such, she was ready to sacrifice her happiness for the common good and ignored her abasement. Thirdly, in her self-sacrifice, Sarah was altruistic and sensitive. Such submission, however, should not be interpreted as weakness but courage and strength. This is because the presence, representation and participation of women in every institution and society are indispensable for the growth of a people or nation and their absence can lead to the annihilation of a nation.

The stereotyped representation of women as subjects for objectification because of either their beauty or silence must be criticised and deconstructed to re-centralise the roles, strength and capability of women. While we can learn from the 'tragic heroism' of Sarah, we are also challenged to know, based on our present-day challenges, struggles and limitations, that good intentions are never enough reasons to debase one's self-worth. If Sarah gave her self-worth in exchange for the life of her husband, then, the story should be understood within its context. As certain stories from the sacred Scripture have guided feminist struggles against patriarchal ideologies, it is crucial to see how the silence of Sarah in Gen 20:1-18 does not lay the foundation for an androcentric assumption that supports the abuse, oppression and dehumanisation of women. An awareness of our stories, especially considering the socio-economic situation of our time, can motivate women to act as support systems for their husbands or families. Nevertheless, such acts of heroism should not be misinterpreted for cowardice or inability.

\section{F REBEKAH'S SEXUAL LAUGHTER AND ITS MORAL IMPLICATIONS}

The use of the word yitzhak, from the root word $(s \bar{a} h a q)$, is a very important usage in the Old Testament, especially in Genesis narratives. The definition of the word seems to cover many things, from laughing to making jest, sport, play,

36 Paolo Torresan, "Silence in the Bible," n.p. Cited 6 May 2021. Online: https://jbqnew.jewishbible.org/assets/Uploads/313/313_Silence2.pdf. 
toy with as of conjugal caresses and make a toy of. ${ }^{37}$ It also means to joke, amuse oneself or fondle. ${ }^{38}$ Sometimes it even means 'to insult' since a certain laughter may imply the ridicule of the person being laughed with or laughed at. ${ }^{39}$ In all Old Testament narratives, the word șăhaq as a verb appears 20 times in Genesis, twice in Judges and twice in Exodus. Given the concentration of the verb in Genesis, one begins to get the feel of the special place șạhaq has in Genesis narratives. First, the word overshadows the Abraham story: from the encounter between Sarah and God (Gen 18:13; 21:6; 18:15; 18:15), Sarah's monologue (21:6), Abraham's monologue (17:17), Sarah and Ishmael (21:9), Rebekah and Isaac (26:8), Lot and his sons-in-law (19:14) and between Joseph and Potiphar's wife $(39: 14,17)$.

Second, the frequent occurrence of șạhaq (believed to mean 'to laugh' or to 'make fun') in the Abraham narrative serves to characterise one of the thematic discussions in the story namely the impossibilities of and doubts about the accomplishments of God in the life of the patriarchs and matriarchs of Israel. Concerning doubts, it is interesting to note that the act of 'laughing' by a character (or characters) usually comes up at an important moment in the story. Consider for instance, Sarah's laughter at God during an especially important theophany in Gen 18:13;21:6;18:15, Rebekah's laughter at a point she was supposed to be hiding her relationship with Isaac in Gen 26:8 and Lot's sons inlaw's laughter at a time the message of Lot should have been taken seriously (19:14). Thus, the doubts of Sarah, Abraham and even Lot's sons in-law serve to further affirm the potency of God in bringing to fulfilment his promise.

Furthermore, the issue of doubt (expressed in laughter) can be closely associated with the motif of sarcasm or contestation, that is, the disapproval of or conflict with a particular action, event or character. In some of the Genesis narratives where the verb root șăhaq is used, the doubt in the actions of the characters signalled a certain sarcasm or rebellion against the other character in question. For instance, in Gen 21:9, șăhaq happened on the day of the weaning of Isaac in which Sarah felt that Hagar's son mocked her. Other instances include the sexual fondling of Isaac and Rebekah in the land of Gerar, an action that may have enticed the one who witnessed it or the one to whom it was directed. Thus, yitzhak (from the verb root șăhaq), which technically means to laugh, is not always for positive reasons. To laugh at a person could be taken as to make jest of, to caress, to joke or even to insult.

37 Brown, F., S.R. Driver and Charles A. Briggs, The Brown-Driver-Briggs Hebrew and English Lexicon, with an Appendix Containing the Biblical Aramaic (BDB; Peabody: Hendrickson, 2001), 8119.

38 Holladay, A Concise Hebrew and Aramaic Lexicon, 7153.

39 See also Victor P. Hamilton, The Book of Genesis: Chapters 1-17 (Grand Rapids: Eerdmans, 1990), 74. 
Interestingly, the use of the expression șa haq or any other form of its usage usually depicts the reaction of a person of lower status towards one of a higher status - of Sarah towards God, of the child of the slave girl towards Sarah, of Isaac and Rebekah towards Abimelech and of Lot's sons in-law towards Lot. When a slave is laughing at a master, a subject laughing at the king or the created laughing at the creator, then, this is a laughter of rebellion or rejection. It is a non-verbal response either of unbelief or of contestation. Knowing that șăhaq means to laugh but also to make jest or joke about something or someone, the account of the action of Isaac and Rebekah that caught the attention of Abimelech may not only be described as having sexual fun but also of making a joke or mockery of or castigating Abimelech.

To have been caught by Abimelech means that Isaac and Rebekah were having sexual fun in the open space, as such, Isaac and Rebecca breached the rules of public decency. Isaac and Rebecca's sexual laughter traversed and broke the borders of supposed social cultural green spaces. Open spaces or squares are usually guarded or protected spaces. The display of sexual affection in the open space was not common during the period and is still not accepted in most places and cultures today. In places and cultures where such is accepted, the action has slowly emerged with time. Public places could be settings for religious, cultural, political and economic activities but not for sexual displays especially on the part of a woman. Although the Old Testament narrates cases of sexual licentiousness or rape, none was said to have taken place in the open space.

Isaac, with the support of Rebekah, decided to flaunt their relationship status openly to reveal the truth to the Gerarites. With the support of Isaac, Rebekah violated the rules of using public spaces to express sexual affection, especially of the need to show respect to others and to self, as a married woman. As women were restricted in many ways from participating in the public religious, political or social events, so also were they restricted from exhibiting sexual affection in the open. However, the assumption that a married woman, or any other woman, cannot express her desire or affection in the open is a prejudice against women found in male-dominated societies. Rebekah, with the help of Isaac, flaunted her sexuality in the open, breaking the borders, refusing to be silenced, caged or victimised under the unjustified control of men, hierarchy, structures, institutions and religion.

By flaunting affection in the public glare, Isaac is sending a message that Rebekah is his wife, as such, cannot be taken into another man's harem. However, why would Isaac participate in such an act in public if it would jeopardise his quest? Was he no longer afraid of his life on the account of the beauty of Rebekah (Gen 26:6-7)? Maybe Isaac was mocking a social system, a patriarchal social system in which women could easily be objectified because of their beauty. Maybe Isaac was rebelling against a political culture that allows 
those in privileged positions to take advantage of the vulnerability of the weak. Based on its context, therefore, the sexual laughter of Isaac and Rebekah comes across as a rebellion against characters that objectify femininity and female beauty. The sexual laughter of Isaac and Rebecca also comes across as a rebellion against institutions and systems that oppress and instrumentalise women and the weak.

Another interrelated matter is the point that Rebekah and Isaac seemed to have used sexual humour to protest sexual oppression, that is, the use of power and supremacy to influence, subjugate and control how women should use their bodies and with whom. The repeated narratives in Gerar reflect a certain social culture in which leaders or those in higher authority can bring into their harem any woman they desire in order to have sexual knowledge of them, irrespective of the woman's marital status. Isaac and Rebekah possibly displayed their sexual affection in the open space to keep Rebekah from being taken into Abimelech's harem. However, by violating the public space, Rebekah was expressing a public statement of disapproval, rejection and contestation of the use of women and their femininity.

\section{G SISTER-WIFE STORIES IN GEN 20:1-18 AND 26:1-12: A CONTEXTUAL APPROPRIATION}

Without disregarding the import of the social, political and religious context of the world of Gen 20:1-18 and 26:1-11, this section will consider some of the moral implications of the narratives of Abraham and Isaac in Gerar in the context of our contemporary society. To begin with, Abraham's and Isaac's concealment of the truth of the relational status between them and their wives was first triggered by the want to satisfy human needs or rather to seek greener pastures. Certain distress situations expose people to vulnerable circumstances that cause them to adopt solutions that may be intrinsically evil. The act of putting the lives of the matriarchs at risk was simply wrong and the means deployed by the patriarchs to save their own lives in Gerar cannot be justified morally. We are challenged, based on our struggles with these texts, that we must always bear in mind the moral maxim that good intentions are never enough. We must keep an eye on the consequences of our actions. Hence, as much as we pay attention to the "ethics of intention/motivation," we must pay attention to the "ethics of means," that is, things we employ in the service or the telos (end of a moral event).

In a way, some of the things we articulate as the norms, ethos or culture of a society are not good in themselves; for instance, the cultural assumption that women are inferior to men and men should assert their superiority. There are also sexual stereotypes or assumptions such as women's bodies are owned and to be controlled by men or it is the duty of women to meet the sexual needs of men. These assumptions and others have helped in promoting violence against women 
and sadly, some of these assumptions are given biblical backing. Given the socio-historical and religious contexts of the time, the story of Abraham, Isaac, Sarah and Rebekah in Gerar, and other similar stories, cannot be used as biblical stories to encourage or permeate evil. The patriarchs may never have thought their actions would be interpreted later in the history of humanity as guiding norms for both good and bad actions. Thus, it is important to stop using what we regard as abnormal today but 'normal' in biblical times to justify abnormal/violent practices as adult persons and minors.

Furthermore, Abraham and Isaac were once in positions of decision making. Their decisions to pass their wives as their sisters were choices made based on the challenges of the time. Little did they know that their actions would have consequences for generations after them. Sometimes, we can be blinded by a narrow focus on the realities of our time and in the process, we make decisions that may later generate or cause havoc, not only to ourselves but also to the generation(s) that will come after us. A remarkable example is the slave trade and its history. We must exercise extreme care about our actions today that we do not initiate or perpetuate actions/practices that in the future will become justifications for evils we never intended.

Genesis 20:1-18 and 26:1-11 are also stories that remind us of how lack of a true knowledge of God could be linked to instances of moral failure, including lack of moral accountability, a faulted understanding of human sexuality, disregard for the worth and dignity of human persons and lack of moral responsibility toward the other, to mention a few. One cannot absolutely claim that a lack of knowledge of God can make people susceptible to living a nonmoral life. However, morality and moral standards are aspects of human life that are very difficult to handle without a reference to a supreme being to whom our negative and positive actions are accountable.

The lessons of Gen 20:1-18 and 26:1-11 also confront us with the issues surrounding the compliance of women in reinforcing patriarchal patterns of politics and de-humanisation. We have in the stories of Sarah and Rebekah two sides of how women deal with patriarchalism as a culture. In Sarah, on one hand, we have a woman who in her response accepted the deal of deceit initiated by her husband. Based on the socio-cultural setting, one does not see the silence of Sarah as out of the ordinary. However, the unsettling issue is that by being a tacit accomplice, the character of Sarah in Gen 20:1-18 unravels the problem of women who participate in promoting cultures and customs that debase womanhood or femininity.

Nevertheless, the tragic heroism of Sarah shows how women could serve as support systems to their husband especially in times of crises. Providing support systems must not necessarily mean giving support that will have negative 
impacts on a woman such as endangering life or promoting sexual violence or disregard for the dignity of women as persons.

In the action of Rebekah, we recognise a certain level of resistance and transformation that can empower us to fight to change the metanarrative. Considering the standards of the time, we have in Rebekah the case of an unusual woman who, given the right support by her husband, was able to brake barriers and boundaries that negate human flourishing. As already analysed, Isaac and Rebekah's expression of their affection in the public space was an act of rebellion, a bold disapproval of the institutions and systems that oppress and instrumentalise women. Although the situational contexts may vary, sexual exploitation is an attitude that pervades every culture. While most women have continued to be treated as objects of sex and pleasure by men, a few women have broken through the barrier of sexual exploitation by speaking up against the objectification, oppression and marginalisation of women.

With the help of men, who sometimes could be the initiator, women today have become prophetic voices against the objectification, exploitation and oppression of women. They have established organisations, institutions and movements for the protection of women such as The Global Initiative to Fight Human Trafficking, \#MeToo, \#SPARK (Sexualization Protest Action Resistant Knowledge), the \#For Every Girl Campaign, The Empower Foundation, and many more. These movements work against (a) the hypersexualised models of femininity in the media that is destroying the psychological and mental health of many girls today; (b) harmful gender stereotypes of women; (c) prostitution, sex trafficking, sexual slavery and (d) women's responsibility and participation in the oppression of women. Like Rebekah, their voices may not be powerful enough now, but they are resistant, rebellious and insistent calling for the rejection of stereotyped portrayals of women in today's culture.

The place and role of women in society today have improved greatly, with new social cultural institutions, customs and practices that guard against the dehumanisation, exploitation and oppression of women. However, human dignity is still not the general experience of every woman. In reading the story of Abraham and Isaac, we lend our voice to the continuous discussions of the social, cultural and political fight against the critical reality of today's women.

\section{H CONCLUSION}

This contribution has analysed some aspects of Gen 20:1-18 and 26:1-16 through a reflection on the relationship between the texts in question, situational contexts and exegetical study of the narratives, the problem of deception in the stories and its moral emphasis as well as the implication of the silence, verbal and non-verbal responses of the matriarchs in the narrative. The study notes that women were used as objects of bargaining and especially as objects of sexual exploitation. 
Patriarchalism is discussed as the dominant perspective or background for the certain actions against and behaviours toward women, especially in the many forms of objectification and commodification of women. However, the article highlights another point, which is that the social, moral and historical lessons of Gen 20:1-18 and 26:1-16 should be understood and interpreted within the context of the traditions that produced the texts. This point is emphasised because it challenges us, in our time, to avoid using what we regard as abnormal today but 'normal' in biblical times to justify abnormal, oppressive, and violent practices against women. In addition, we are urged to exercise extreme care that we do not initiate or perpetuate actions/practices that in the future will become justification for evils we never intended. Although the passing of Sarah and Rebekah as sisters (actions that could have led to their sexual objectification, dehumanisation and exposure to harm) reflects the culture of a certain time, it should not be used to encourage, perpetuate and promote sexual objectification, commodification and dehumanisation of women today. Unlike the father, the son must behave differently. The son should not make the same mistakes as the father. The complicit silence of Sarah has not helped women so well. Therefore, like Rebekah, given the right support, women should be able to speak out and act against patriarchal ideologies and practices that are detriment to women.

\section{BIBLIOGRAPHY}

Alter, Robert. The Art of Biblical Narrative. New York: Basic Books, 1981.

Bartak, Christopher. "Held down through Their Bodies: Sexual Objectification of Women and the Legitimization of Patriarchy." Ph.D. thesis, University of Oklahoma, Graduate College, 2015.

Bartky, S. L. Femininity and Domination: Studies in the Phenomenology of Oppression. New York: Routledge, 1990.

Brown, F., S.R. Driver and Charles A. Briggs. The Brown-Driver-Briggs Hebrew, and English Lexicon, with an Appendix Containing the Biblical Aramaic BDB. Peabody: Hendrickson, 2001.

Clines, D.J.A. The Theme of the Pentateuch. Journal for the Study of the Old Testament Supplement Series 10. Sheffield: JSOT Press, 1978.

Coats, George W. Genesis, with an Introduction to Narrative Literature. The Forms of the Old Testament Literature 1. Grand Rapids: Eerdmans, 1983.

Culey, Robert C. Studies in the Structure of Hebrew Narrative. Philadelphia: Fortress, 1976.

Demsky, Aaron. "Looking through the Window: A Gendered Motif." No Pages. (2017) Cited 2 February 2020. Online: https://www.thetorah.com/article/lookingthrough-the-window-a-gendered-motif.

Exum, Cheryl J. Fragmented Women Feminist (Sub)versions of Biblical Narratives. Journal for the Study of the Old Testament Supplement Series 163. Sheffield: JSOT Press, 1993.

Frolov, Serge. "Sarah, Rebekah, and the Unchangeable Ruble: Unrecognized Folkloric Background of the "Wife-Sister" Stories in Genesis." Biblische Notizen 150 (2011): 3-8. 
112 Uzukwu, "Woman as a Bargaining Object," OTE 34/1 (2021): 89-113

Fuchs, Esther. Sexual Politics in the Biblical Narrative Reading the Hebrew Bible as a Woman. Sheffield: Sheffield Academic Press, 2003.

Greengus, Samuel. "Sisterhood Adoption at Nuzi and the 'Wife-Sister' in Genesis." Hebrew Union College Annual 46 (1975): 5-31.

Gruenfeld, D.H., M.E. Inesi, J. C Magee and A.D. Galinsky. "Power and the Objectification of Social Targets." Journal of Personality and Social Psychology 95 (2008): 111-127.

Hamilton, Victor P. The Book of Genesis: Chapters 1-17. New International Commentary on the Old Testament. Grand Rapids, MI: Eerdmans, 1990.

Hezser, Catherine. Jewish Slavery in Antiquity. New York: Oxford University Press, 2005.

Holladay, William L. A Concise Hebrew and Aramaic Lexicon of The Old Testament: Based upon the Lexical Work of Ludwig Koehler and Walter Baumgartner, A Concise Hebrew and Aramaic Lexicon of the Old Testament. Grand Rapids: William Eerdmans, 1971.

Kandiyoti, Deniz. "Bargaining with Patriarchy." Gender and Society 2 (1988): 274290.

Keller, C.A. "Die Gefaihrdung der Ahnfrau': Ein Beitrag zur gattungs- und motivgeschichtlichen Erforschung alttestamentlicher Erzahlungenr." Zeitschrift für die Alttestamentliche Wissenschaft 66 (1954): 181-190.

Korsak, Mary Phil. "God's Laughter." Pages 163-173 in Building Bridges in a Multifaceted Europe: Religious Origins, Traditions, Contexts and Identities. Journal of the European Society of Women in Theological Research 14. Edited by Sabine Bieberstein, Kornélia Buday and Ursula Rapp. Leuven: Peteers, 2006.

Niditch, Susan Underdogs and Tricksters: A Prelude to Biblical Folklore. New Voices in Biblical Studies. San Francisco: Harper \& Row, 1987.

Noth, Martin. A History of Pentateuchal Traditions. Englewood Cliffs, Prentice-Hall, 1972.

Pace, Sharon Jeansonne. The Women of Genesis: From Sarah to Potiphar's Wife. Minneapolis: Fortress Press, 1990.

Petersen, David L. "A Thrice-told Tale: Genre, Theme, and Motif." Biblical Research 18 (1973): 30-43.

Philo. Volume VI: On Abraham. On Joseph: Moses I and II. Translated by F. H. Colson. Loeb Classical Library 289. Cambridge: Harvard University Press, 1950.

Robinson, Robert B. "Wife and Sister through the Ages: Textual Determinacy and the History of Interpretation." Semeia 62 (1993): 103-104.

Sarna, Nahum M. Genesis: The Traditional Hebrew Text with the JPS Translation. The JPS Torah Commentary. Philadelphia, PA: The Jewish Publication Society, 1989.

Seeman, Don. "The Watcher at the Window: Cultural Poetics of a Biblical Motif." Prooftexts 24 (2004): 1-50.

Speiser, Ernest A. "The Wife-Sister Motif in the Patriarchal Narratives." Pages 15-28 in Biblical and Other Studies I. Edited by A. Altmann. Waltham: Brandeis University Press, 1963.

. Genesis. Garden City: Doubleday, 1964. 
Uzukwu, "Woman as a Bargaining Object," OTE 34/1 (2021): 89-113 113

Thompson, Stith. Motif-Index of Folk-Literature II. Centraltrykkeriet: Copenhagen, 1956.

Torresan, Paolo. "Silence in the Bible." n.p. Cited 6 May 2021. Online: https://jbqnew.jewishbible.org/assets/Uploads/313/313_Silence2.pdf.

Uzukwu, Gesila. "Religion and Religiosity of Women in the Scripture and Africa: A Study of a Living Paradox." Abuja Journal of Philosophy and Theology 4 (2014): 37-55.

Van Seters, John. Abraham in History and Tradition. New Haven: Yale University Press, 1975.

Vawter, Bruce. On Genesis: A New Reading. Garden City: Doubleday, 1977.

Westermann, Claus. Genesis 12-36: A Commentary. Minneapolis: Augsburg Press, 1985.

White, Hugh C. Narration and Discourse in the Book of Genesis. Cambridge: Cambridge University Press, 1991.

Gesila Nneka Uzukwu, Department of Philosophy and Religious Studies, Nasarawa State University, Keffi. E-mail: gesynneka@yahoo.co.uk. ORCID: https://orcid.org/0000-0003-3285-4468. 